\title{
Notes on the taxonomy of mountain viscachas of the genus Lagidium Meyen 1833 (Rodentia: Chinchillidae)
}

\author{
Pablo Teta ${ }^{* 1}$ and Sergio O. Lucero' \\ 'División Mastozoología, Museo Argentino de Ciencias Naturales “Bernardino Rivadavia” Avenida Ángel Gallardo 470, C1405DJR. \\ Buenos Aires, Argentina. E-mail antheca@yahoo.com.ar (PT), serglucero@yahoo.com.ar (SOL) \\ * Corresponding author
}

\begin{abstract}
Mountain viscachas of the genus Lagidium Meyen 1833 are medium-to-large hystricomorph rodents (1.5 -- $3 \mathrm{~kg}$ ) that live in rocky outcrops from Ecuador to southern Argentina and Chile. Lagidium includes more than 20 nominal forms, most of them based on one or two individuals, which were first described during the $18^{\text {th }}$ and $20^{\text {th }}$. Subsequent revisions reduced the number of species to three to four, depending upon the author. Within the genus, Lagidium viscacia (Molina, 1782) is the most widely distributed species, with populations apparently extended from western Bolivia to southern Argentina and Chile. We reviewed $>100$ individuals of Lagidium, including skins and skulls, most of them collected in Argentina. We performed multivariate statistical analysis (i. e., principal component analysis [PCA], discriminant analysis [DA]) on a subset of 55 adult individuals grouped according to their geographical origin, using 16 skull and tooth measurements. In addition, we searched for differences in cranial anatomy across populations. PCA and DA indicate a moderate overlap between individuals from southern Argentina, on one hand, and northwestern Argentina, western Bolivia and northern Chile, on the other. The external coloration, although variable, showed a predominance of gray shades in southern Argentina and yellowish gray in northwestern Argentina. Specimens of southern Argentina were characterized by their bigger overall size, nasals expanded in its front half, and narrow dorsal root of the zygomatic process of the maxillary, while those of northwestern Argentina were smaller, with nasals lacking expansions and the dorsal root of the zygomatic process of the maxillary broad. Our study provides coincident results from quantitative and qualitative morphology that allow us to clearly differentiate southern Argentinean populations of Lagidium viscacia from those of northwestern Argentina and western Bolivia. The oldest available name for the populations from southern Argentina, sometimes referred as L. boxi, is moreni, a taxon with an unclear type locality. The status of the populations from northwestern Argentina and western Bolivia is relatively more complex, since at least eight nominal forms were described from this general area and because our sampling is far from being extensive. In addition, is also unclear if these populations correspond to one or more species, as well as their degree of differentiation from L. viscacia s. s. Without analyzing topotypes of all nominal forms and adequate samples across the entire distribution range, it is premature to put forward a formal taxonomic proposal; as such, at this moment we prefer to maintain those populations from northwestern Argentina, western Bolivia and central Chile under L. viscacia.
\end{abstract}

El género Lagidium Meyen 1833 incluye más de 20 formas nominales, la mayoría de ellas basadas en uno o dos ejemplares, descriptas entre finales del siglo XVIII y principios del XX. Revisiones posteriores redujeron este número a tres o cuatro especies, dependiendo del autor. Más recientemente, el uso de técnicas moleculares ha demostrado que esos números tampoco son representativos de la diversidad real de este género. Lagidium viscacia (Molina 1782) es un taxón ampliamente distribuido, con poblaciones desde el oeste de Bolivia hasta el sur de Argentina y Chile. Sin embargo, su variación morfológica y geográfica no ha sido evaluada con metodologías modernas y series extensas de ejemplares. En este trabajo se revisaron > 100 individuos, incluyendo pieles y cráneos colectados principalmente en Argentina. Se realizaron análisis multivariados (i. e., análisis de componentes principales, discriminantes) sobre un subconjunto de 55 ejemplares adultos agrupados según su procedencia geográfica y a partir de 16 medidas cráneo-dentarias. En los análisis de componentes principales y discriminantes se registró una superposición moderada entre individuos de distintas localidades del sur de Argentina por un lado y del noroeste de Argentina, oeste de Bolivia y norte de Chile por el otro. La coloración externa, a pesar de ser muy variable, mostró una predominancia de tonos grises hacia el sur de Argentina y amarillentos hacia el noroeste. Los especímenes del sur de Argentina, aquí referidos como L. moreni, se distinguieron por su mayor tamaño general, sus nasales más anchos y expandidos en su mitad anterior y por tener la raíz dorsal del proceso cigomático del maxilar angosta. Por el contrario, los ejemplares del noroeste de Argentina, que aquí optamos por mantener dentro del concepto de $L$. viscacia, poseen un menor tamaño general, los nasales angostos y sin expansiones y la raíz dorsal del proceso cigomático del maxilar ancha.

Key words: Caviomorpha; Chinchilloidea; Hystricomorpha: taxonomy.

¿ 2017 Asociación Mexicana de Mastozoología, www.mastozoologiamexicana.org

Introduction

Mountain viscachas of the genus Lagidium Meyen 1833 (Rodentia, Chinchillidae) are medium-to-large hystricomorph rodents ( 1.5 to $3 \mathrm{~kg}$ ) that live in rocky outcrops from Ecuador to southern Argentina and Chile (Spotorno and Patton 2015). The taxonomic history of this genus, similar to other Neotropical mammals, can be divided into three main stages. During the first period, that spans between the late $18^{\text {th }}$ century and the early $20^{\text {th }}$ century, more than 20 nominal forms were described, mostly based on one or two specimens from their respective type localities (e. $g$., Thomas 1907). At the second stage, under the paradigm of the biological species concept, most of these names were regarded as synonyms, depending upon the author (some of them recognized as subspecies), of three to four more widely distributed species (e. g., Cabrera 1961). Finally, the use of molecular markers in recent years suggested that this scenario is not representative of the real taxonomic diversity within the genus (Spotorno et al. 2004, Ledesma et al. 2009). 


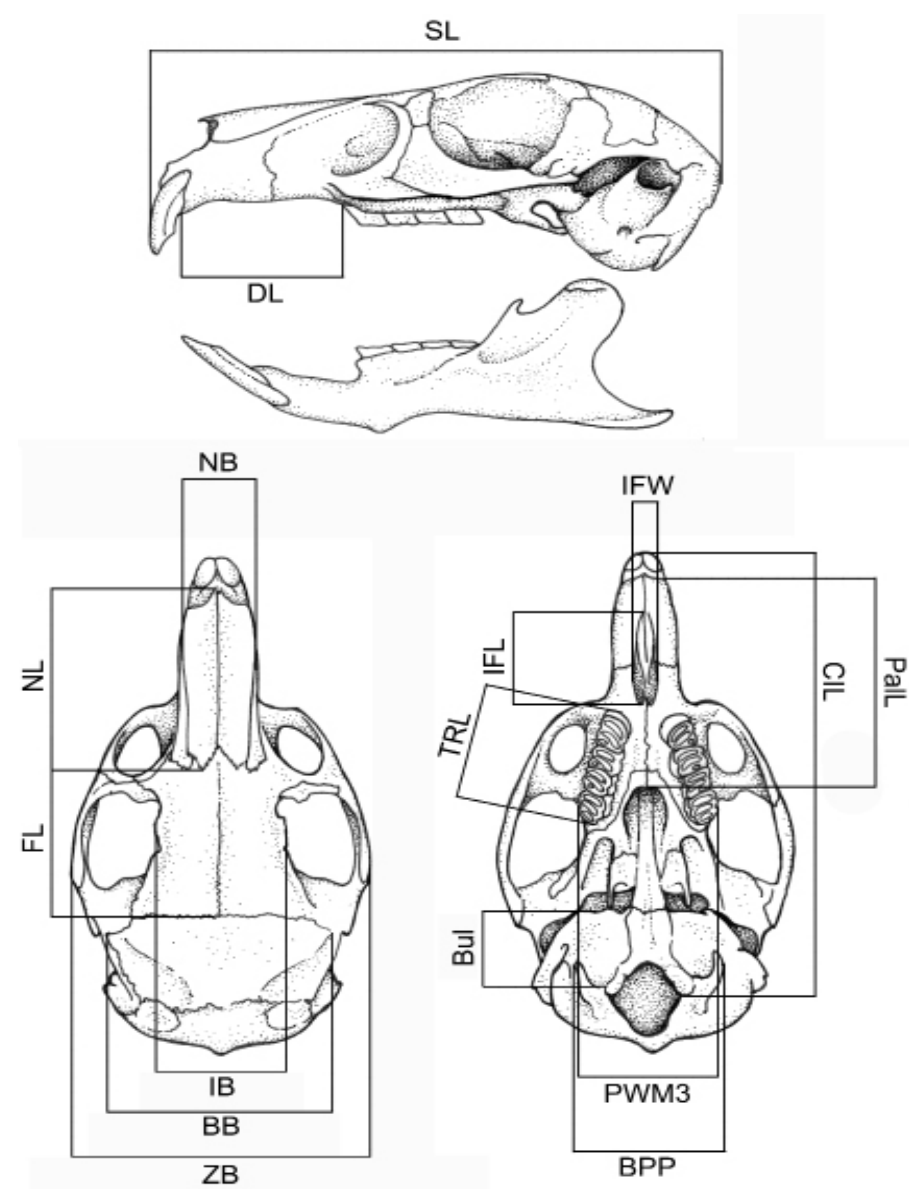

Figure 1. Measurements used in the multivariate analysis. For measurement abbreviations: see the section Materials and Methods.

Hayman (in Ellerman 1940:230-231), based on the specimens housed at the British Museum, was the first reviewer of the genus Lagidium. This author recognizes four species, from north to south: L. peruanum Meyen 1833, L. viscacia (Molina 1782), L. boxi Thomas 1921, and L. wolfsohni (Thomas 1907). Hayman (in Ellerman 1940) used size, presence of dorsal stripes and coloration pattern as the main diagnostic features for delimiting the different species. Subsequent authors subsumed boxi (e. g., Cabrera 1961) and peruanum (e. g., Spotorno and Patton 2015; but see Ledesma et al. 2009) under $L$. viscacia. Overall, the profusion of names within this genus was reflected by the recognition of multiple subspecies, especially within viscacia (e. g., Cabrera 1961; Crespo 1963; Mann 1978). More recently, Spotorno et al. (2004) and Ledesma et al. (2009), combining molecular and morphometric evidences in the context of the description of a new species from Ecuador (L. ahuacaense), recognized several molecular lineages within Lagidium that partially coincide with the groups recovered in their multivariate analysis of metrical data. In addition, Ledesma et al. (2009) found that L. viscacia, as currently conceived, was not resolved as a monophyletic group. Recently, Spotorno and Patton (2015), in a conservative approach, recognized only three species (L. ahuacaense, L. viscacia, and $L$. wolffsohni) and discussed extensively the taxonomic history of the genus (see Table 1 for a synthesis of the main taxonomic hypothesis within Lagidium). Taxonomic uncertainties within Lagidium are related to the deficient definition of some taxa, the apparently limited morphological differentiation between species, and the poor representation of specimens in biological collections (Spotorno and Patton 2015).

In this work we studied, from a qualitative and quantitative approach, Argentinean and Bolivian populations referred to $L$. viscacia, in order to better understand their geographic morphological variation pattern. Based on our results, we consider that taxonomic changes are needed.

\section{Materials and Methods}

One hundred and fifty specimens referred to as Lagidium viscacia from Argentina and western Bolivia were examined in this study (see Appendix 1). For comparative purposes, we also included six specimens of $L$. peruanum from northern Chile. Sixteen craniodental variables were measured in adult specimens $(n=55)$ in order to quantitatively describe the size and shape of the major skull structures, as follows (Figure 1): skull length (SL), condylo-incisive length (CIL), zygomatic breadth (ZB), braincase breadth (BB), palatilar length (PalL), incisive foramina length (IFL), incisive foramina width (IFW), diastema length (DL), maxillary toothrow length (alveolar) (TRL), palatal width at M3 (PWM3), breadth across paraoccipital process (BPP), nasal length (NL), nasal width (NW), interorbital breadth $(\mathrm{IB})$, frontal length $(\mathrm{FL})$, and bullar length (BuL). All measurements were obtained with digital calipers to the nearest 0.05 $\mathrm{mm}$, and were log-transformed before the multivariate statistical analyses.

Geographic trends and the degree of differentiation between samples were examined by multivariate statistical procedures, including principal component analysis (PCA) and canonical variate discriminant analysis (DA). Small samples from different localities were grouped following the geographic proximity criterion (e. g., Musser 1968) and the similarity between the geomorphological characteristics of the localities sampled (e. g., mountain slopes, relief; see Chiquito et al. 2014). Samples with only one individual were not included in DA. Samples were labeled in the figures and tables using the following abbreviations: Argentina: $\mathrm{CH}=$ Chubut Province, $\mathrm{JU}=$ Jujuy Province, $\mathrm{LR}=$ La Rioja Province, $\mathrm{ME}=$ Mendoza Province, $\mathrm{NQ}=$ Neuquén Province, $\mathrm{RN}=$ western Río Negro Province, $\mathrm{SA}=$ Salta Province, $\mathrm{SJ}=$ San Juan Province, $\mathrm{SO}=$ Somuncurá, $\mathrm{TU}=$ Tucumán Province. Bolivia: $\mathrm{BO}=$ western Bolivia. Chile: $\mathrm{PE}=$ Northern Chile (Figure $2 \mathrm{C}$ ). The sample from RN includes two topotypes of $L$. boxi Thomas 1921, and the sample from $\mathrm{SO}$ includes the type series of $L$. $v$. somuncurensis Crespo 1963. Previous studies on Lagidium have shown that differences between sexes are not significant (cf. Pearson 1948); consequently, we pooled males and females in the multivariate analyses.

The variation in cranial and external qualitative anatomical characters was also documented. The anatomical terminology used to describe skull structures follows Cherem and Ferigolo (2012). Pelage coloration was assessed by side-by-side comparisons of specimens. 

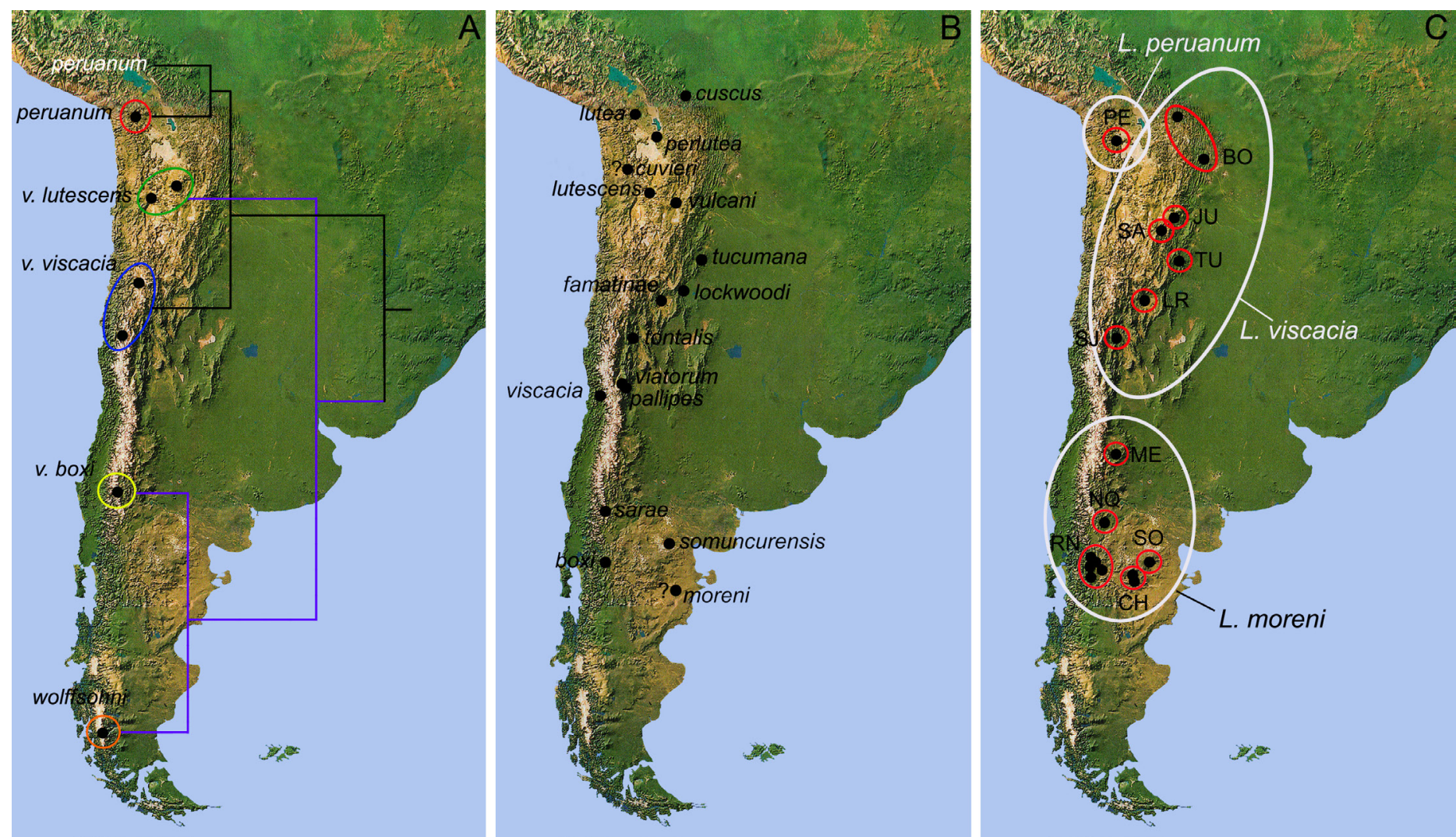

Figure 2. Map of southern South America depicting: A) A simplified tree of the phylogenetic hypothesis for Lagidium based on cytb sequences presented by Ledesma et al. (2009). B) Type localities of the nominal forms included by Spotorno and Patton (2015) within the synonymy of Lagidium viscacia (e. g., Cabrera 1961; Mann 1978; Anderson 1997; the nominal forms L. crassidens Philippi 1896 and L. crinigerum Phillipi 1896, included by Osgood 1943 under the synonymy of L. v. viscacia, were not mapped due to uncertainties about their type localities. C) Geographic samples defined in this work (see Materials and Methods for abbreviations). White ellipses illustrate the taxonomic hypothesis proposed in this work.

\section{Results}

The principal component analysis revealed two major morphometric groups spanning along the $1^{\text {st }}$ and $2^{\text {nd }}$ principal components, which accounted for $\sim 70 \%$ of the variance (Figure 3, Table 2). All craniometric characters were positively correlated with $\mathrm{PC1}$, indicating size variation as the main source

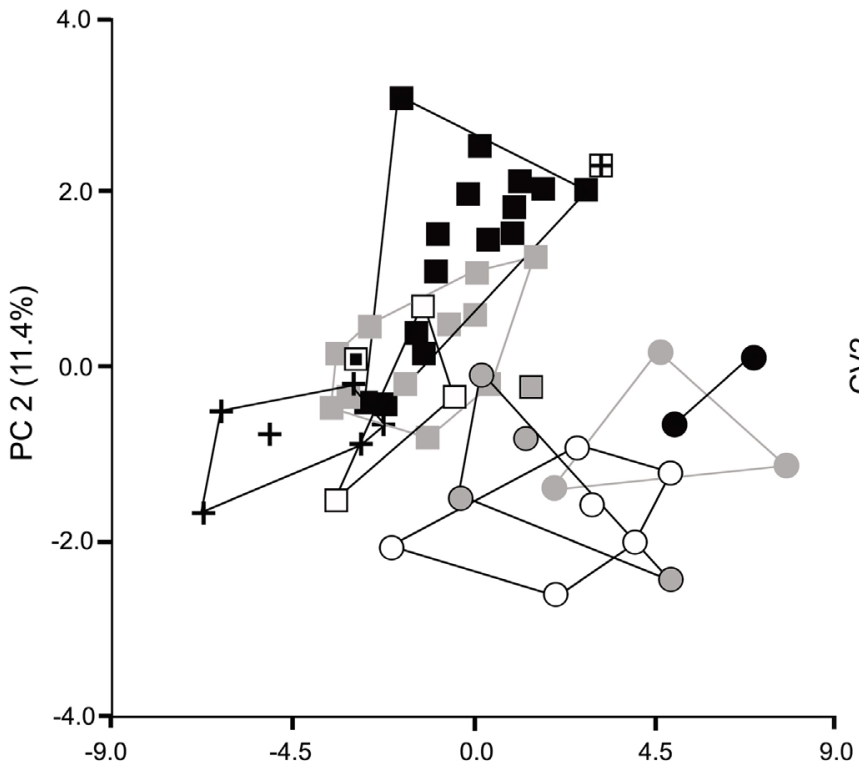

PC $1(59.1 \%)$ of differentiation between samples (Figure 3, Table 2). The first group was composed of specimens from southern Argentina (i. e., $\mathrm{CH}, \mathrm{NQ}, \mathrm{RN}$ and $\mathrm{SO}$ ), while the second encompassed animals from northwestern Argentina (i. e., JU, LR, SA, SJ, TU) and western Bolivia (BO) plus L. peruanum from northern Chile (PE). This latter sample (PE) appeared as the smallest in cranial size within this second group. Overall, the overlap in multivariate

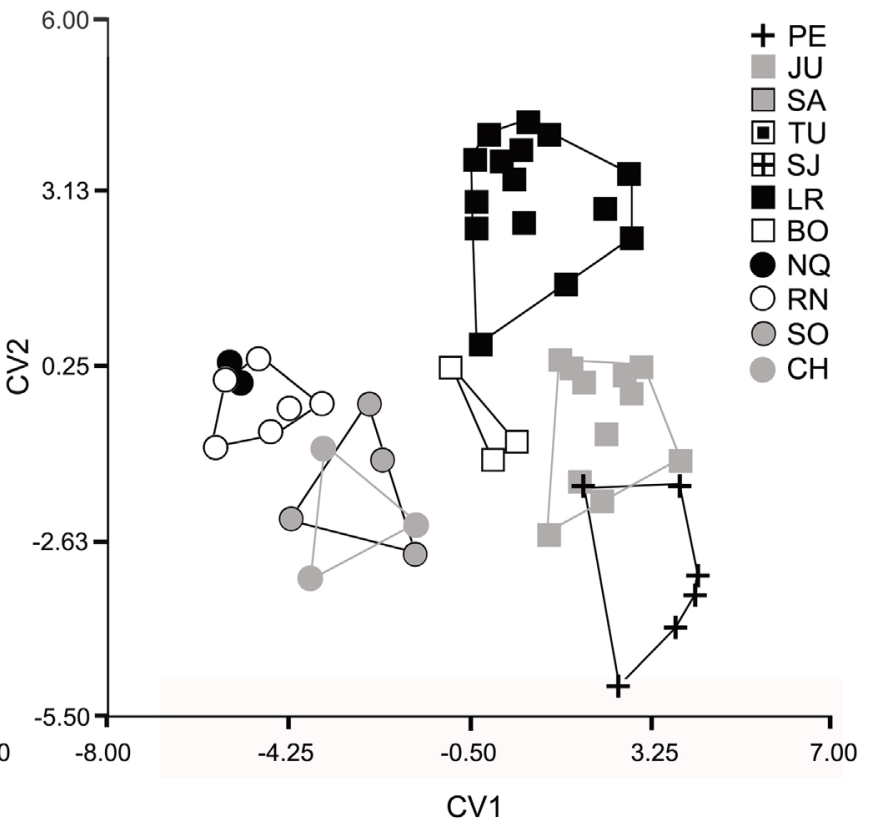

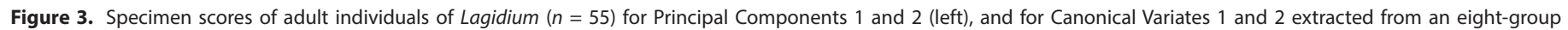
discriminant function analysis (right). See Materials and Methods for the explanation of the abbreviations. 
Table 1. Main taxonomic hypothesis for the species of the genus Lagidium (Rodentia, Chinchillidae), including the arrangement of subspecies proposed by different authors.

\begin{tabular}{|c|c|c|c|}
\hline Hayman (in Ellerman 1940) & Cabrera (1961) & Woods and Kilpatrick (2005) & Spotorno and Patton (2015) \\
\hline Lagidium peruanum & Lagidium peruanum & Lagidium peruanum & Included within L. viscacia \\
\hline L.p.peruanum & L.p.peruanum & L.p.peruanum & \\
\hline L.p.arequipe & & L.p.arequipe & \\
\hline L.p.inca & L.p.inca & L.p.inca & \\
\hline L.p.pallipes & & L.p.pallipes & \\
\hline L.p.punensis & & L.p.punensis & \\
\hline L.p. saturata & L.p. saturatum & L.p. saturata & \\
\hline L.p. subrosea & L.p. subroseum & L.p. subrosea & \\
\hline Lagidium viscacia & Lagidium viscacia & Lagidium viscacia & L. viscacia \\
\hline \multirow[t]{2}{*}{ L.v. viscacia } & L.v. viscacia & L. v. viscacia & \\
\hline & L.v.boxi & L.v.boxi & \\
\hline \multirow[t]{2}{*}{ L.v.cuscus } & L.v. cuscus & L.v.cuscus & \\
\hline & L.v. cuvieri & L.v. Cuvieri & \\
\hline L.v.famatinae & L.v.famatinae & L.v.famatinae & \\
\hline L.v. lockwoodi & L.v. lockwoodi & L.v. lockwoodi & \\
\hline \multicolumn{4}{|l|}{ L.v. lutea } \\
\hline \multirow[t]{2}{*}{ L.v.moreni } & L.v.moreni & L.v.moreni & \\
\hline & L.v. pallipes & & \\
\hline \multirow[t]{2}{*}{ L.v. perlutea } & & L.v. perlutea & \\
\hline & L.v.sarae & L.v. sarae & \\
\hline L.v. tontalis & & L.v. tontalis & \\
\hline L.v. tucumana & L.v. tucumanum & L.v. tucumana & \\
\hline L.v. viatorum & & L.v. viatorum & \\
\hline L.v. vulcani & L.v. vulcani & L.v. vulcani & \\
\hline L. boxi & & & Included within L. viscacia \\
\hline \multicolumn{4}{|l|}{ L.b.boxi } \\
\hline \multicolumn{4}{|l|}{ L.b.sarae } \\
\hline Lagidium wolffsohni & & Lagidium wolffsohni & $\begin{array}{l}\text { Lagidium wolffsohni } \\
\text { Lagidium ahuacaense }\end{array}$ \\
\hline
\end{tabular}

space among geographic samples within the first and second groups was moderate to high (Figure 3).

The discriminant analysis correctly allocated almost all specimens in their respective geographic sample (Table 3 ). The $1^{\text {st }}$ and $2^{\text {nd }}$ canonical variates accounted for $\sim 80 \%$ of the variance. Specimens from southern Argentina (i. e., $\mathrm{CH}, \mathrm{NQ}, \mathrm{RN}$ and SO) differed from the other samples by having overall larger and more robust crania, with markedly larger characters related to BB, BPP, PalL, and NW (Figure 3, Table 2 and 3).

Among the Argentinean samples, the two main groups identified through PCA can be diagnosed based on the distribution of qualitative characters. The external coloration was relatively variable among samples, a fact previously noted by Pearson (1948). However, there is a clear predominance of grayish-colored specimens, with well-marked and usually broad dorsal stripes among southern ( $\mathrm{CH}, \mathrm{RN}$, SO; Figure 4A) and west-central (ME) Argentinean samples and yellowishgray individuals (more or less suffused with orange), with diffuse to well-marked, usually narrow, dorsal stripes among the populations from northwestern Argentina (JU, LR, SA, TU; Table 4; Figure 4B). Individuals from NQ were metrically nested within samples from southern Argentina, although their external coloration was mostly yellowish-gray. A main difference between both groups was the shape of nasals, which were relatively large with a conspicuous widening in the distal half in specimens from southern Argentina (i. e., $\mathrm{CH}, \mathrm{NQ}, \mathrm{RN}$ and
$\mathrm{SO})$, and narrow with nearly straight and parallel borders in the remaining samples (i. e., JU, LR, SA, SJ, TU; Figure 5). In addition, the dorsal root of the zygomatic process of the maxilla was narrow in the first group and broad in the second (Figure 5).

Samples from BO and PE have a similar cranial architecture relative to specimens from northwestern Argentina, differing slightly from them in the quantitative characters.

\section{Discussion}

The present study provides mostly coincident results from quantitative and qualitative morphological traits, which allow differentiating the southern Argentinean samples of Lagidium viscacia from those of northwestern Argentina, as well as separating both from $L$. peruanum (Figure $2 \mathrm{C}$ ). The magnitude of these differences stands at the species level (cf. Ledesma et al. 2009; Spotorno and Patton 2015); the question that remains, however, regards the proper allocation of names to the southern and northwestern Argentinean forms.

Specimens from west-central (ME) and southern Argentina are characterized by grayish colorations $(\mathrm{CH}, \mathrm{RN}, \mathrm{SO}$; except NQ which is yellowish gray), with well- marked and usually broad dorsal stripes, nasals expanded anteriorly and narrow dorsal roots of the zygomatic process of the maxilla. Four nominal taxa traditionally linked with viscacia were described from southern Argentina: moreni Thomas 1897, boxi Thomas 1921, sarae Thomas and St. Leger 1926, and somuncurensis 

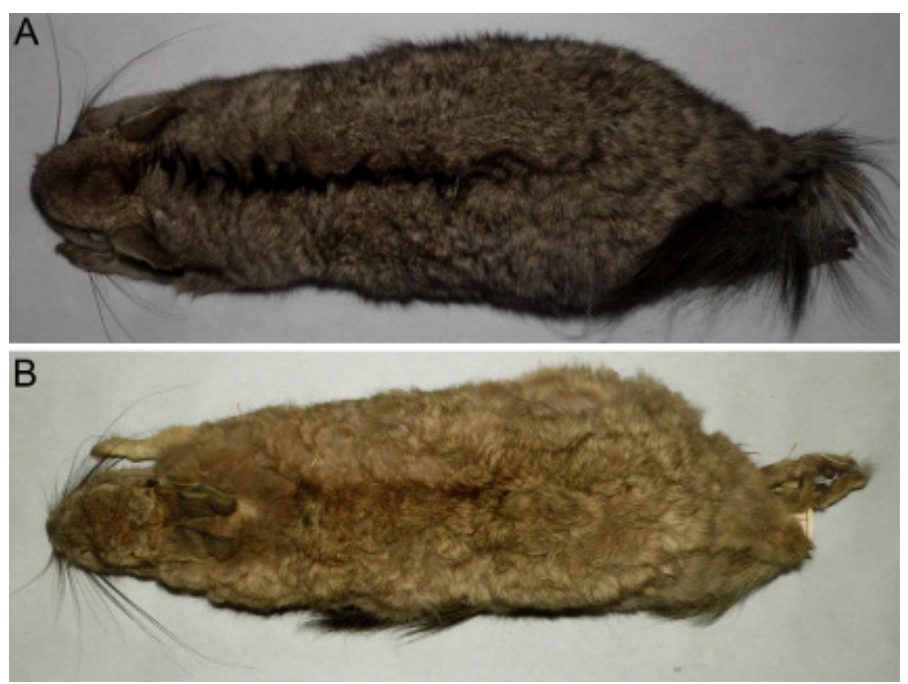

Figure 4. External view of the dorsal coloration of different populations of Lagidium: A) southern Argentina (MACN 14313; Pilcaniyeu, Río Negro; here referred as L. moreni). B) north-western Argentina (MACN 34.258; Sierra de Velazco, La Rioja; here referred as $L$. viscacia). Not in scale.

Crespo 1963 (Figure 2B). Hayman (in Ellerman 1940), Pearson (1995) and Spotorno et al. (2004) used boxi as the appropriate name for southern Argentinean and Chilean samples. Within this context, the status of moreni, included by Hayman (in Ellerman 1940) under his concept of viscacia (against Osgood 1943:141, which suggested that this taxon would be closely allied to boxi) should be adequately addressed, since this name precedes boxi. The type locality of moreni is unclear, a fact that restrains taxonomic assessments. Thomas (1897: 466) first referred it to "hills near Chubut, Eastern Patagonia," but subsequently considered it as "unknown, as 'Chubut' is a province of considerable size, and there is no evidence as to the detailed location where the specimen was obtained" (Thomas 1921: 181). Lagidium is broadly distributed on western and central Chubut province, with some isolated population reaching its

Table 2. Specimen scores of adult individuals of Lagidium $(n=55)$ for Principal Components 1 and 2, and for Canonical Variates 1 and 2 extracted from an eight-group discriminant function analysis. See materials and methods for the explanation of the abbreviations.

\begin{tabular}{lcccc}
\hline & CP1 & CP2 & CV1 & CV2 \\
\hline SL & 0.32 & 0.03 & -0.28 & 0.85 \\
LCI & 0.32 & 0.07 & 0.30 & -0.82 \\
IB & 0.19 & 0.03 & 0.18 & -0.02 \\
ZB & 0.31 & -0.04 & -0.38 & 1.57 \\
BB & 0.21 & -0.34 & 0.09 & -1.06 \\
LN & 0.27 & -0.01 & 0.17 & -0.20 \\
NW & 0.24 & -0.36 & 0.18 & -0.68 \\
FL & 0.20 & -0.11 & -0.05 & -0.02 \\
DL & 0.29 & 0.07 & 0.70 & -0.6 \\
IFW & 0.02 & 0.60 & 2.26 & -0.08 \\
IFL & 0.21 & 0.37 & -0.68 & 0.91 \\
TRL & 0.28 & 0.09 & -0.83 & 0.49 \\
PalL & 0.30 & -0.05 & -0.35 & -0.48 \\
BPP & 0.26 & -0.04 & -1.09 & -0.01 \\
PWM3 & 0.28 & 0.01 & 0.35 & -0.83 \\
BuL & 0.10 & 0.47 & 1.30 & 0.27 \\
Eigenvalue & 9.45 & 1.83 & 9.36 & 5.61 \\
\% Variance & 0.59 & 0.11 & 49.5 & 29.69 \\
\hline
\end{tabular}

easternmost locality record near $-65^{\circ} \mathrm{W}$ (Chebez et al. 2014). The specimens studied from Chubut and other areas of southern Argentina formed close clusters in the multivariate space, suggesting that only a single species is present in this area.

Most of the samples from northwestern Argentina (e. g., $\mathrm{JU}, \mathrm{LR}, \mathrm{SA}, \mathrm{SJ}, \mathrm{TU}$ ) are characterized by yellowish-gray colorations, with diffuse to well-marked dorsal stripes, nasals not expanded anteriorly, and a broad dorsal root of the zygomatic process of the maxilla. At least five nominal forms were described from northwestern Argentina (i. e., tucumana Thomas 1907, vulcani Thomas 1919, lockwoodi Thomas 1919, famatinae Thomas 1920, tontalis Thomas 1921; Figure 2B). Osgood (1943) argued that "The physical conditions under which the animals [in reference to these nominal forms] live in

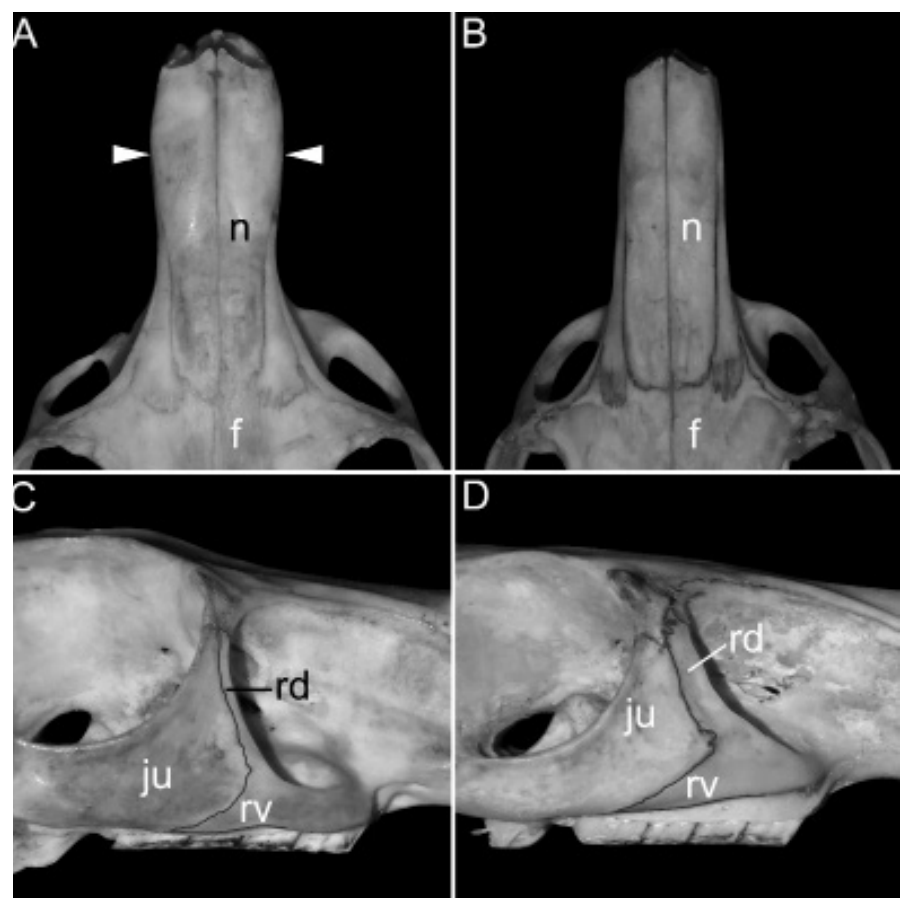

Figure 5. Anatomic details of the skulls of Lagidium moreni $(A, C)$ and L. viscacia $(B$, D): A, C) MACN 13933 (NQ), note the nasals [n] anteriorly expanded and the narrow dorsal root of the zygomatic process of the maxilla [rd]; B, D) MACN 18829 (JU), presenting nasals [n] not expanded anteriorly and a broad dorsal root of the zygomatic process of the maxilla [rd]. Other abbreviations: $f=$ frontal; ju = jugal; $r v=$ ventral root of the zygomatic process of the maxilla.

this region are fairly uniform and one finds it difficult to accept the assumption that all these names are well founded...it seems desirable to reduce all of these names to subspecific status." The cluster of specimens from western Bolivia in the multivariate space is close to those of northwestern Argentina and share a similar cranial architecture. However, both clusters differ in coloration, which was mostly grayish for those from western Bolivia. At least three nominal forms were described for Bolivia: cuscus Thomas 1907, lutea Thomas 1907, and perlutea Thomas 1907 (Figure 2B). Anderson (1997) recognized a single species in Bolivia (L. viscacia), with three subspecies (L. v. cuscus, L. v. lutea, L. v. perlutea), mapping several localities geographically close from the hypothesized distribution of $L$. peruanum in the Peruvian Highlands. In turn, Osgood (1943) referred populations from northern Chile and adjoining Boliv- 
Table 3. Classification matrix of geographic samples of Lagidium determined by the eight-group discriminant function analysis (see also Figure 3 and Table 2). See Materials and Methods for the explanation of the abbreviations.

\begin{tabular}{lccccccccc}
\hline Sample & BO & CH & JU & LR & NQ & PE & RN & SO & $\begin{array}{c}\text { Error } \\
\text { (\%) }\end{array}$ \\
\hline BO & 3.00 & 0 & 0 & 0 & 0 & 0 & 0 & 0 & 0 \\
CH & 0 & 3.00 & 0 & 0 & 0 & 0 & 0 & 0 & 0 \\
JU & 0 & 0 & 10.00 & 0 & 0 & 1.00 & 0 & 0 & 9.09 \\
LR & 1.00 & 0 & 0 & 14.00 & 0 & 0 & 0 & 0 & 6.67 \\
NQ & 0 & 0 & 0 & 0 & 2.00 & 0 & 0 & 0 & 0 \\
PE & 0 & 0 & 0 & 0 & 0 & 6.00 & 0 & 0 & 0 \\
RN & 0 & 0 & 0 & 0 & 0 & 0 & 6.00 & 0 & 0 \\
SO & 0 & 1 & 0 & 0 & 0 & 0 & 0 & 3.00 & 25.00 \\
Total & 4.00 & 4.00 & 10.00 & 14.00 & 2.00 & 7.00 & 6.00 & 3.00 & 6.00 \\
\hline
\end{tabular}

ian areas as L. v. cuvieri, suggesting their potential synonymy with lutea. With the evidences currently available, it is unclear whether those populations in northwestern Argentina and western Bolivia correspond to a single or several species, or whether they belong to L. viscacia s. S. (as some molecular evidences suggest; see the discussion below).

From the above, it is clear that the taxonomic scenario within Lagidium remains poorly defined, especially for populations towards the north-central portion of their distribution. This situation is shared by other genera of caviomorph rodents, in which discrete morphological differentiation in cranial features is apparently limited (e. g., Dasyprocta [e. g., Teta and Lucero 2016], Galea [e. g., Bezerra 2008]). Overall, our results contradicts the traditional view that considers L. viscacia as a largely distributed rodent species (e. g., Spotorno and Patton 2015). The evidence reported here, plus the one derived from of previous molecular approaches (e. g., Spotorno et al. 2004; Ledesma et al. 2009) strongly suggest that this taxon, as currently delimited, encompasses two or perhaps more species.

Our analysis, although preliminary, demonstrates that the Argentinean populations of $L$. viscacia correspond at least to two different species based on morphological and molecular evidences (cf. Ledesma et al. 2009). Those populations from westcentral and southern Argentina (and possibly those on adjoining areas of southern Chile) could be preliminarily recognized as $L$. moreni, as discussed above. According to genetic data, this species is sister to L. wolffsohni, which is found farther to the south in montane areas of Argentina (Santa Cruz province) and Chile. Although we have not analyzed any specimens of $L$. wolffsohni, we preliminarily considered this species as distinct based on its striking orange coloration, short ears and large overall size (cf. Hayman [in Ellerman 1940]). As regards the samples from northwestern Argentina, the available evidence is inconclusive, since some molecular-based studies linked some populations in Jujuy (Argentina) and Antofagasta (Chile) to L. viscacia s. s. (specimens from central Chile; Spotorno et al. 2004), while data allocated these populations as a sister to a clade formed by the populations recognized here as L. moreni plus L. wolffsohni (Ledesma et al. 2009). Thus, without analyzing the topotypes of all nominal forms as well as adequate samples across the entire distributional range of the genus, it is premature to put forward any formal taxonomic proposal; we prefer to maintain those populations from northwestern Argentina, western Boliva and central Chile under L. viscacia.
Table 4. Variation on the occurrence of different types of dorsal coloration and development of the dorsal stripe among geographic samples of Lagidium. See materials and methods for the explanation of the abbreviations.

\begin{tabular}{lcccc}
\hline & \multicolumn{2}{c}{ Dorsal coloration } & \multicolumn{2}{c}{ Dorsal stripe } \\
\cline { 2 - 5 } & grayish & yellowish-gray & well marked & difuse \\
\hline BO & $3(100 \%)$ & 0 & $1(33.3 \%)$ & $2(6.7 \%)$ \\
CH & $2(100 \%)$ & 0 & $2(100 \%)$ & 0 \\
JU & $2(22.2 \%)$ & $7(77.8 \%)$ & $8(88.9 \%)$ & $1(11.1 \%)$ \\
LR & 0 & $76(100 \%)$ & $3(4.0 \%)$ & $73(96.0 \%)$ \\
ME & $1(100 \%)$ & 0 & $1(100 \%)$ & 0 \\
NQ & $1(16.7 \%)$ & $5(83.3 \%)$ & $6(100 \%)$ & 0 \\
RN ${ }^{1}$ & $18(94.7 \%)$ & $1(5.3 \%)$ & $18(94.7 \%)$ & $1(5.3 \%)$ \\
SA & 0 & $8(100 \%)$ & $4(50.0 \%)$ & $4(50.0 \%)$ \\
SO & $3(100 \%)$ & 0 & $3(100 \%)$ & 0 \\
TU & 0 & $1(100 \%)$ & 0 & $1(100 \%)$ \\
\hline
\end{tabular}

'Two specimens from RN have a nearly uniform orange coloration, darker at the midline (MACN 36.135, 36.136; skulls unavailable); one specimen from SJ has a light gray dorsum frosted with white, and a light orange venter (MACN 18829).

Nominal forms such as pallipes Bennett 1835 and viatorum Thomas 1921 were not included in our study, nor were specimens from the northern Mendoza province, an area where the southern and northwestern groups could be in contact. Unfortunately, the only specimen examined from southern Mendoza province lacked its skull. Additional data, including molecular evidence, is much needed in order to clearly demarcate the distributional boundaries between species, especially in highly complex topographical areas such as the high Andean of northwestern Argentina, western Bolivia and northern Chile.

\section{Acknowledgements}

We thank G. D'Elía (Colección de Mamíferos de la Universidad Austral de Chile), Ricardo Ojeda (Colección de Mamíferos del Instituto Argentino de Investigación de Zonas Áridas) and D. Udrizar Sauthier for allowing access to specimens under their care. Special appreciation is extended to G. Cassini for his help with multivariate statistical analysis. G. D'Elía and two anonymous reviewers provided useful comments on an earlier version of this manuscript. María Elena Sánchez-Salazar edited the English manuscript with support of THERYA through a CONACYT grant.

\section{Literature cited}

ANDERSON, S. 1997. Mammals of Bolivia, taxonomy and distribution. Bulletin of the American Museum of Natural History 231:1-652.

BezerRA, A. 2008. Revisão taxonômica do gênero Galea Meyen, 1832 (Rodentia, Caviidae, Caviinae)." Ph.D. dissertation, Universidade de Brasília. Brasilia, Brazil.

Cabrera, A. 1961. Catálogo de los mamíferos de América del Sur. Parte II. Revista del Museo Argentino de Ciencias Naturales "Bernardino Rivadavia" Ciencias Zoológicas 4, 309-732.

Chebez, J. C., U. F. J. Pardiñas, and P. Teta. 2014. Mamíferos terrestres de la Patagonia y el sur de Chile. Vazquez Mazzini Editores. Buenos Aires, Argentina.

Cherem, J. J., AND J. Ferigolo. 2012. Descrição do sincrânio de Cavia aperea (Rodentia, Caviidae) e comparação com as demais espécies do gênero no Brasil. Papéis Avulsos de Zoologia 52:21-50. 
Chiquito, E., G. D'Elia, and A. R. Percequillo. 2014. Taxonomic review of genus Sooretamys Weksler, Percequillo \& Voss (Rodentia: Cricetidae: Sigmodontinae): an integrative approach. Zoological Journal of the Linnean Society, 171:842-877.

CRESPO, J. A. 1963. Dispersión del chinchillón, Lagidium viscacia (Molina) en el noreste de Patagonia y descripción de una nueva subespecie (Mammalia; Rodentia). Neotrópica 9:61-63.

Ellerman, J. R. 1940. The families and genera of living rodents. Vol. 1. Rodents other than Muridae. Trustes of the British Museum (Natural History).

Gallardo, M. H., and D. Reise. 1992. Systematics of Aconaemys (Rodentia, Octodontidae). Journal of Mammalogy 73:779-788.

Ledesma, K. J., F. A. Werner, A. E. Spotorno, and L. H. Albuja. 2009. A new species of Mountain Viscacha (Chinchillidae: Lagidium Meyen) from the Ecuadorean Andes. Zootaxa 2126:41-57.

Mann F., G. 1978. Los pequeños mamíferos de Chile. Zoología (Gayana) 40:1-342.

Musser, G. G. 1968. A systematic study of the Mexican and Guatemalan gray squirrel, Sciurus aureogaster F. Cuvier (Rodentia: Sciuridae). Miscellaneous Publications, Museum of Zoology, University of Michigan 137: 1-112.

OsGood, W. H. 1943. The mammals of Chile. Field Museum of Natural History, Zoological Series 30:1-268.

Pearson, O. P. 1948. Life history of mountain viscachas in Peru. Journal of Mammalogy 29:345-374.

Pearson, O. P. 1995. Annotated keys for identifying small mammals living in or near Nahuel Huapi National Park or Lanin National Park, southern Argentina. Mastozoología Neotropical 2:99-148.

Spotorno, A. E., AND J. L. Patton. 2015. Superfamily Chinchilloidea Bennett, 1833. Pp. 762-783 in Mammals of South America, Vol. 2: Rodents (J. L. Patton, U. F. J. Pardiñas, and G. D'Elía, eds.). University of Chicago Press. Chicago, U. S. A.

Spotorno, A. E., J. P. Valladares, J. C. Marín, R. E. Palma, and C. ZULETA R. 2004. Molecular divergence and phylogenetic relationships of chinchillids (Rodentia: Chinchillidae). Journal of Mammalogy 85:384-388.

TetA, P., AND S. O. LuCero. 2016. ¿Cuántas especies del género Dasyprocta (Rodentia, Dasyproctidae) hay en Argentina? Mastozoología Neotropical 23:193-199.

ThомAs, O. 1897. On a new species of Lagidium from the eastern coast of Patagonia. Annals and Magazine of Natural History, series 6, 19:466-467.

ThomAs, O. 1907. On a remarkable mountain viscacha from southern Patagonia, with diagnoses of other members of the group. Annals and Magazine of Natural History, series 7, 19:438- 444.

Thomas, O. 1921. A new mountain vizcacha (Lagidium) from $\mathrm{N}$. W. Patagonia. Annals and Magazine of Natural History, series 9, 7:179-181.

Woods, C. A., AND C. W. KilPATRICK. 2005. Infraorder Hystricognathi. Pp.1538-1600 in Mammal species of the world, $3^{\text {rd }}$ ed., (Wilson, D. E., and D. M. Reeder, eds.). Johns Hopkins Press. Baltimore, U. S. A.

Associated editor: Guillermo D'Elia

Submitted: April 18, 2016; Reviewed: October 26, 2016;

Accepted: January 7, 2016; Published on line: January 19, 2017

\section{Appendix 1.}

List of specimens used in the morphological analyses, including skins and skulls. Acronyms correspond to the following collections. Argentina: Buenos Aires, Museo Argentino de Ciencias Naturales "Bernardino Rivadavia" (MACN-Ma), Mendoza. Colección de Mamíferos del Instituto Argentino de Investigación de Zonas Áridas (CMI). Chile: Valdivia, Colección de Mamíferos de la Universidad Austral de Chile (UACH). US refers to field numbers of Daniel Udrizar Sauthier.

Lagidium moreni $(n=35)$. Argentina: Chubut: Cushamen (MACN-Ma 16521), Sierra de Talagapa (US, without number), Estancia La Maroma (US, without number). Mendoza: Malargue, $3 \mathrm{~km}$ S Puesto Peralito, $120 \mathrm{~km}$ E de Malargue (CMI without number). Neuquén: Catan-Lil, Las Coloradas (MACN-Ma 13620, 14312), Zapala, Parque Nacional Laguna Blanca (MACN-Ma 14897, 14898, 14899). Río Negro: Bariloche, El Bolsón (MACNMa 13936, 13937, 13946, 13947, 13949, 13951, 13952, 13955, 13956, 13958), Bariloche, Lago Martín (MACN-Ma 36.135, 36.136), Ñorquinco, Ñorquinco (MACN-Ma 13930, 13932, 13933, 13934, 13944, 16474), Pilcaniyeu, Pilcaniyeu (MACN-Ma 44.25, 14313), Valcheta, Campana Mahuida (MACN-Ma 14308, 14309, 14310, 14538, 14539, 14542).

Lagidium viscacia ( $n=125)$ : Argentina: Jujuy: locality not recorded (MACN-Ma 8.2, 31.11), Rinconada, Cerro Guadalupe (MACN-Ma 39.499, 39.500), Tilcara, Tilcara (MACN-Ma 8.18, 8.19), Valle Grande, Sierra de Zenta (MACN-Ma 32.66, 32.67), Yavi, La Laguna (MACN-Ma 27.99, 27.100), Departamento Yavi, Sierra de Cochinoca (MACN-Ma 14708), Yavi Chico (MACNMa 36.432, 41.54). La Rioja: locality not recorded (MACN-Ma 41.545), Famatina, Famatina (MACN-Ma 34.271), Sanagasta, Sierra de Velasco (MACN-Ma 34.202, 34.203, 34.204, 34.205, $34.206,34.207,34.208,34.211,34.212$, 34.213, 34.214, 34.215, $34.217,34.219,34.221,34.222,34.223,34.224,34.225,34.226$, $34.227,34.228,34.229,34.230,34.231,34.232,34.233,34.234$, $34.236,34.237,34.238,34.239,34.240,34.241,34.242,34.243$, $34.244,34.245,34.246,34.249,34.250,34.253,34.254,34.256$, $34.251,34.252,34.257,34.259,34.260,34.261,34.263,34.264$, $34.265,34.266,34.271,34.319,34.1184,34.1185,34.1186$, 34.1189, 34.1190, 34.1191, 34.1192, 34.1193, 34.1194, 34.1195, $34.1196,34.1197,34.1198,34.1199,34.1200,34.1201,34.1202$, 34.1204, 34.1205, 34.1206, 34.1207, 34.1208, 34.1209, 34.1210, 34.1211, 34.1212, 34.1213). Salta: Los Andes, San Antonio de los Cobres (MACN-Ma 26.194, 26.195, 26.196, 26.197, 26.198, 26.199), Rosario de Lerma, Chorrillos (MACN-Ma 30.113, 30.114), Santa Victoria, Lizoite (MACN-Ma 41.26, 41.27, 41.37, 41.97). San Juan: Iglesia, Parque Nacional San Guillermo (MACN-Ma 18829). Tucumán: locality not recorded (MACN-Ma 4.382, 30.81), Chicligasta, Sierra del Aconquija (MACN 30.80).

Bolivia: locality not recorded (MACN-Ma 13097). La Paz: Pedro Domingo Murillo, Nuestra Señora de La Paz (MACN-Ma 33.41, 33.42, 33.43), Pacajes (MACN-Ma 50.279, 50.280).

Lagidium peruanum $(n=6)$ : Chile: Tarapacá: Parinacota (UACH 711, 712, 717, 719, 720, 721). 
34 THERYA Vol. 8 (1): $27-33$ 